\title{
THE EFFECT OF ORGANIZATIONAL SUPPORT ON WORK SATISFACTION IN REGIONAL SECRETARIAT EMPLOYEES IN PARIAMAN DISTRICT
}

\author{
NIKA SAPUTRA \\ nikachaniago@rocketmail.com
}

\begin{abstract}
Abstrak: Sumber daya manusia merupakan salah satu sumber daya yang ada dalam suatu perusahaan disamping sumber daya yang lain, misalnya modal, material, mesin, sehingga menjadi bermanfaat. Untuk itu instansi mulai berusaha untuk tetap unggul dalam persaingan yang serba kompetitif tersebut dengan berupaya menciptakan kualitas sumber daya manusianya dan presentatif. Penelitian ini bertujuan untuk memberikan bukti bahwa untuk mengetahui ada tidaknya pengaruh dukungan organisasi terhadap kepuasan kerja Pegawai Sekretariat Daerah Kabupaten Pariaman. Pengumpulan data dilakukan dengan metode survei dengan kuesioner. Teknik analisa data yang digunakan dalam penelitian ini adalah analisis deskriptif dan kuantitatif. Data yang dikumpulkan merupakan data primer dan sekunder yang dapat digolongkan sebagai variabel bebas dan variabel terikat. Dukungan Organisasi (variabel pengaruh), dan Kepuasan Kerja Pada Pegawai Sekretariat Daerah Kabupaten Pariaman (variabel terpengaruh). Pengujian hipotesis dalam penelitian ini menggunakan uji regresi linier Sederhana. Berdasarkan hasil penelitian diketahui bahwa terdapat pengaruh positif dan signifikan antara dukungan organisasi terhadap dan Kepuasan Kerja Pada Pegawai Sekretariat Daerah Kabupaten Pariaman didapat $T_{\text {hitung }}$ lebih besar dari $T_{\text {tabel }}$ dimana 2,806>2,015 dengan signifikansi 0,007<0,05.
\end{abstract}

Kata kunci : Dukungan Organisasi, Kepuasan Kerja Pegawai

Abstract: Human resources are one of the resources that exist in a company besides other resources, for example capital, materials, machinery in the company, so that it becomes useful. For this reason, companies are beginning to strive to excel in such competitive competition by trying to create quality and presentative human resources. This study aims to provide evidence that to determine whether or not there is an influence of organizational support on the work satisfaction of the Regional Secretariat Staff in Pariaman Regency. Data collection is done by survey method with a questionnaire. The data analysis technique used in this study is descriptive and quantitative analysis. The data collected is primary and secondary data which can be classified as independent variables and dependent variables. Organizational Support (influence variable), and Job Satisfaction in Regional Secretariat Staff of Pariaman Regency (affected variable). Testing the hypothesis in this study using a simple linear regression test. Based on the results of the study, it is known that there is a positive and significant influence between organizational support for and Job Satisfaction in the Regional Secretariat Staff of Pariaman Regency, obtained by a calculation that is greater than the Ttable where 2.806 $>2.015$ with a significance of $0.007<0.05$.

Keywords: Organizational Support, Employee Job Satisfaction

\section{A.Introduction}

Human resources is one of the resources that exist in a company in addition to other resources, such as capital, materials, machinery in the company, so that it becomes useful. For this reason, companies have begun to strive to stay ahead in the competitive competition by trying to create quality and presentive human resources. 
To get trained and skilled human resources for a business organization, of course it can be traveled by conducting training, education, and guidance for its human resources.

Job satisfaction has a considerable influence on the productivity of an organization either directly or indirectly. Job satisfaction is a picture of the attitude of workers towards their work and everything related to the work environment. Someone will see that the work being faced has a positive meaning so that it gives happiness when it likes the work being carried out, or vice versa causes inner pressure or stress when disliking. One element that influences the behavior of employees themselves is the organizational support that surrounds it. The organization in this case the Pariaman Regency Regional Secretariat, positive support from the leadership and all employees will create a conducive work situation. By getting this support, employee performance will be encouraged to improve.

The organization's function is to coordinate employee behaviors in order to work well so that organizational goals are achieved. Openness of an organization to the environment will create cooperation and maintain the life force of the organization. Organizational support is focused on the favorable treatment and level of employees involved in a positive reciprocal relationship with the organization. In order to meet socio-emotional needs and to assess the benefits of increased work effort, employees form general perceptions about the extent to which organizations value their contributions and care about their well-being. The organizational support is felt to increase employee obligations to help the organization achieve its goals, commitments, effective employees to help the organization, and employee expectations that improved performance will be appreciated. The results of employee perceptual behavior for organizational support will include improvements in performance, extra-roles, decreases in behavior behavior and withdrawals such as absenteeism and disputes.

Job satisfaction is basically something that is individual. Everyone who works expects satisfaction from his place of work. Job satisfaction can affect positive and negative behavior towards work, meaning that if satisfaction is obtained, then good things will be obtained from the work. Conversely, if job satisfaction is less achieved in his work, then something that is not expected will be obtained in his work. For that we need to understand what must be done to create job satisfaction.

Many factors can affect one's job satisfaction, the factors themselves in their role of providing satisfaction to employees / employees but this also depends on the personal value of each employee itself. According to Hasibuan (2009: 203), job satisfaction can be influenced by several factors including: 1) Reward fair and reasonable services; 2) Proper placement in accordance with the expertise; 3) The severity of the work; 4) The atmosphere and work environment; 5) Equipment that supports the implementation of work; 6) The attitude of the leader in his leadership; and 7) Watch work attitude or not

In an organization many problems are associated with organizational support, if organizational support in the form of providing human resources, work facilities and infrastructure to meet and stimulate various work needs of members, the contribution of organizational support to job satisfaction and work motivation of members of the organization is very large for each members to pursue their careers as well as possible. In organizations, social interaction can occur in the context of individuals and their organizations. Related to that, the concept of organizational support tries to explain the interactions of individuals with organizations that specifically study how organizations 
treat individuals (their members). Organizational support is very important in view of the behavior of workers. Organizations have an obligation to develop a climate that supports consumer orientation (Gronroos: 1990). stated that organizational and management support will increase the motivation of customer orientation behavior of its workers.

Locke (1976) and Scheineder (1998) suggest that individuals are interested and feel comfortable being organized, due to the similarity in characteristics between the two. Meglino (1989) suggests that individuals who have the same values as the organization, then they will easily interact efficiently with the organization's value system, reduce uncertainty, and conflict and increase satisfaction and improve performance. Positive support from the leadership and all employees will create a conducive work situation. By getting this support the performance of members will be encouraged to be better. In addition, support also raises the enthusiasm of the work team so that they can trust and help each other and there is a good relationship between workers in the work environment (Shaametal, 1999).

Flippo (2000) factors that influence employee performance are work motivation, job satisfaction, leadership style, work climate, organizational support, work discipline, motivation and employee ability. Organizational treatment received by employees is captured as an organized stimulus and interpreted as a perception of organizational support. This perception will foster a certain level of trust of employees for the appreciation given by the organization for their contribution (valuation of employees contribution) and organizational attention to their lives (care about employees. Well-being) (Eisenberger, et al. 1986). The level of employee confidence in organizational support will be influenced by their evaluation of experience and observations about the way the organization treats its employees in general (Allen, 1995; Eisenberg et al. 1986).

According to Hutchinson (1997), organizational support can also be seen as organizational commitment to individuals. If in the interaction of individualsorganizations, known as organizational commitment from individuals to the organization, then organizational support means the opposite, namely organizational commitment to individuals (employees) in the organization. Organizational commitment to employees can be given in various forms, including rewards, equal compensation and a fair organizational climate. These forms of support also develop from material (material) forms such as salary, benefits, bonuses, and so on; to those that are intrinsic (non material) such as attention, praise, acceptance, intimacy, information, self-development, and so on.

It can be concluded that organizational support is how companies or organizations value employee contributions to the progress of the company or organization and the company's attention to their lives. 1) Indicator of organizational support according to Eisenberger et al. (1986: 502) are as follows: 2) Awards; The company gives awards / rewards for employee work achievement. 3) Development; The company pays attention to capabilities and provides promotional opportunities for employees. 4) Working conditions; regarding physical and non-physical work environments. 5) Employee welfare; the company cares about the welfare of employees' lives.

\section{B. Research Methods}

Sugiyono (2014: 2) stated in general the research method is defined as a scientific way to obtain data with specific purposes and uses. In conducting a research, E-ISSN: 2657-0300 Lembaga Penelitian dan Penerbitan Hasil Penelitian Ensiklopedia $\quad 71$ P-ISSN: 2657-0319 
it is necessary to determine in advance the research methods we examined. The research conducted aims to determine the effect of organizational support on job satisfaction. Based on the stated research objectives, the method used in this study is the associative quantitative method (Mulia 2019). Data is information that can provide a picture of a situation. The type of data used in this study is primary data, how to obtain it by distributing questionnaires to the parties concerned. So the data is sourced from information provided by Pariaman District Secretariat Staff. According to Arikunto (2006: 130) "Population is the whole subject of research". In this study the population was the Employees of the Pariaman District Secretariat.

\section{Result and Analysis \\ 1. Descriptive Data}

Organizational support is seen from 4 indicators such as awards with a mean score of 4.9 with a percentage of $100 \%$, this means that the Regional Secretariat of Pariaman District has given rewards for employee performance, the development of risk scores of a mean 4.6, with the highest percentage of $98 \%$ This illustrates that the Regional Secretariat of Pariaman Regency has formed a good network that can support the work of employees, working conditions with a mean score of 4.05 percentages of 89\% This shows the working environment at the Pariaman District Secretariat has provided a sense of comfort for employees in doing work, besides that employee welfare with a mean score of 4 with a percentage of $91 \%$ which is the Regional Secretariat of Pariaman Regency not only thinking of employee welfare. In general, it can be said that organizational support is very good, this can be seen from the mean variable score of 4.5. Thus it can be said that the support of the organizations contained in the Pariaman District Secretariat in this study such as awards can be interpreted that the employees of the Pariaman District Secretariat are satisfied with the policies given such as rewarding employees so that spur employees to be more focused in doing their work, while for development can be interpreted that the Regional Secretariat of Pariaman Regency is already good in its application, and is able to provide opportunities to employees in order to improve their capabilities and good cooperation supported by a good working network, and for working conditions it can be interpreted that the Regional Secretariat of the Pariaman District has both in providing working conditions to employees in the form of a comfortable working environment and complete facilities so as to provide its own satisfaction for employees in doing their work and for employee welfare can be interpreted that the Regional Secretariat of Pariaman Regency is already good in providing welfare for employees so as to create enthusiasm and motivation of employees in doing work.

Job satisfaction is seen from 6 indicators such as salary indicator with a mean score of 3.5, the job indicator itself with a mean score of 3.8, a colleague indicator with a mean score of 3.5, a supervision indicator with a mean score of 3.9, a promotion indicator with a score mean 3.6, and work environment indicators with a mean score of 3.9. In general it can be said that job satisfaction is good, as seen from the mean variable score of 3.7. Thus it can be said that job satisfaction possessed by employees contained in the Pariaman District Secretariat in this study such as salary can be interpreted that employees who are in the Pariaman District Secretariat feel satisfied with the salary received on time so that the salary can meet the needs employees, while the indicator of the work itself can be interpreted that employees who are in the 
Pariaman District Secretariat are satisfied because they can master the work given so that employees feel the work done becomes more interesting from time to time. It is also related to the Pariaman Regency Regional Secretariat which provides facilities that are suitable to the needs of work so that employees feel happy in doing the work done. For co-workers indicators, it can be interpreted that employees in the Pariaman Regency Regional Secretariat have a good relationship with co-workers where fellow employees are willing to help overcome work difficulties so that employees do not find difficulties in cooperating with co-workers jointly responsible for output work. Furthermore, supervision indicators can be interpreted that employees in the Pariaman District Secretariat are satisfied with superiors who provide support, assistance, and focus on their subordinates. For promotion indicators it can be interpreted that employees in the Pariaman District Secretariat feel happy with the basis used for promotions based on employee performance so that they open up opportunities to be promoted for employee career advancement. Furthermore, for work environment indicators, it can be interpreted that employees in the Pariaman Regency Regional Secretariat feel that the workplace environment has met hygiene standards so that employees feel comfortable in doing work. However, even so employees in the Pariaman Regency Regional Secretariat need to have to increase employee job satisfaction again in order to achieve maximum results to support employee satisfaction for better work results.

\section{Classic Assumption Test}

Normality test. Normality test is performed to determine whether the data comes from populations that are normally distributed or not. The normality test is carried out using the Kolmogorov-Smirnov test. If the Asymp value. Sig (2-tailed) is greater than> 0.05 , it can be concluded that the data is normally distributed. For more details, see the table below:

Table 1. Normality Test

\begin{tabular}{c|l|c|c}
\hline \hline No & \multicolumn{1}{|c|}{ Variable } & Sig. Value & Description \\
\hline 1 & Support Organizations (X) & 0,200 & Normal \\
\hline 2 & Job satisfaction (Y) & 0,200 & Normal \\
\hline \hline
\end{tabular}

From the table above it can be seen that the significance value is greater than 0.05 . Because the significance is more than 0.05 , the values of each of these variables are normally distributed.

Multicollinearity Test. Multicollinearity test aims to test whether the regression model found a correlation between independent variables. If the independent variables are correlated with each other, then these variables are not orthogonal. Orthogonal variables are independent variables whose correlation value between independent variables is equal to zero. To detect the presence or absence of multicollinearity in the regression model is as follows:

Table 2. Multicollinearity Test Results

\begin{tabular}{c|l|c|c|c|c}
\hline \hline No & \multicolumn{1}{|c|}{ Variabel } & $\begin{array}{c}\text { VIF } \\
\text { Value }\end{array}$ & Tolerance & $\begin{array}{c}\text { VIF } \\
\text { limit }\end{array}$ & Description \\
\hline 1 & $\begin{array}{l}\text { Dukungan } \\
\text { Organisasi (X) }\end{array}$ & 1,393 & 0,718 & 10 & $\begin{array}{c}\text { Tidak Terjadi } \\
\text { Multikolinearitas }\end{array}$ \\
\hline \hline
\end{tabular}

The results of the calculation of the tolerance value indicate that there are no independent variables that have a tolerance value of less than $10 \%$ which means there is no correlation between the independent variables whose values are more than $90 \%$. 
The results of the calculation of the value of the variance inflation factor (VIF) also showed the same thing there is not one independent variable that has a VIF value of more than 10 . So it can be concluded that there is no multicollinearity between the independent variables in the regression model.

\section{Simple Regression Analysis}

The analysis used in this study is a simple linear regression analysis with two predictors namely Support Organizations (X), and job satisfaction (Y). This regression model can be used to partially determine the effect of compensation and organizational support on job satisfaction among employees of the Pariaman Regency Regional Secretariat. Based on the calculation of SPSS for Windows Release 24.0, the regression analysis table is obtained as follows:

Table 4. Simple Regression Analysis

\begin{tabular}{|c|c|c|c|c|c|c|}
\hline \multirow{2}{*}{\multicolumn{2}{|c|}{ Model }} & \multicolumn{2}{|c|}{$\begin{array}{l}\text { Unstandardized } \\
\text { Coefficients }\end{array}$} & \multirow{3}{*}{$\begin{array}{c}\begin{array}{c}\text { Standardized } \\
\text { Coefficients }\end{array} \\
\text { Beta }\end{array}$} & \multirow{3}{*}{$\begin{array}{c}\mathrm{t} \\
0,067 \\
\end{array}$} & \multirow{3}{*}{$\begin{array}{l}\text { Sig. } \\
0,947 \\
\end{array}$} \\
\hline & & \multirow{2}{*}{$\begin{array}{c}\text { B } \\
0,832\end{array}$} & \multirow{2}{*}{$\begin{array}{c}\begin{array}{c}\text { Std. } \\
\text { Error }\end{array} \\
12,371\end{array}$} & & & \\
\hline \multirow[b]{2}{*}{1} & (Constant) & & & & & \\
\hline & $\begin{array}{l}\text { Support } \\
\text { Organizations } \\
(\mathrm{X} 2)\end{array}$ & 1,138 & 0,406 & 0,354 & 2,806 & 0,007 \\
\hline
\end{tabular}

The table above shows that the multiple regression equation obtained from the analysis results, as follows:

$\mathrm{Y}=0,832+1,138 \mathrm{X}$

The regression model has meaning:

a. Constants: 0.832

If the compensation and organizational support variables are considered constant, the average job satisfaction is 0.832 .

b. Regression coefficient X (Organizational Support)

From the calculation of multiple regression obtained coefficients (b) is 1.138. This means that if the organizational support variable increases by 1 (one) point, while the compensation variable is considered permanent it will cause an increase in job satisfaction by 1,138 .

\section{Hypothesis Testing and Discussion on the Effect of Organizational Support on Job Satisfaction in Pariaman Regency Regional Secretariat (Y) employees}

Several studies have been conducted previously in assessing the perception of organizational support. The results of the study were conducted by Eisenberger et al (1986) in "perception of organizational support" The results showed that the perception of organizational support increases employee efforts to achieve organizational goals through greater presence, and this important relationship depends on the ideology of employee exchange. Job Satisfaction is one of the most extensive discussions and constructive studies in the field of psychology and management, perhaps because of its 
effect on other interests of organizational achievement such as employee performance, conceptual appearance and organizational performance.

According to the theory of organizational support employees believe in the extent to which organizational values are contributed and care about how they become better (Eisenberger, Huntington, Hutchison \& Sowa, 1986; Rhoades \& Eisenberger, 2002). This belief is known as the perception of organizational support, the process of type of psychology has an effect on the establishment and behavior. Employees who perceive their organizations as supporting their job satisfaction. More clearly employees who perceive good to his organization will be good and easily arranged about the satisfaction of desires and become better as they see their work environment, one of which is not conductive in the action of achieving work goals, values, consequences, feelings of dissatisfaction. Moreover, these employees may feel dislike of the organization because of their lack of commitment. As unsatisfied is the intention of work dissatisfaction. Finally, the feeling of being more supportive becomes more favored by the organization, comfortable, self-esteem, competition, giving results (Kraiger, Billings \& Isen, 1989).

This research is also supported by research conducted by Deddy. (2016) examined the Effect of Competence, Job Satisfaction, and Organizational Commitment on Employee Performance (Study of the Southeast Minahasa District Inspectorate). Based on the results of competency research, job satisfaction and organizational commitment together / simultaneously affect employee performance, and competency has a significant effect on performance while job satisfaction and organizational commitment does not significantly influence performance. The difference between this research and the research that the researcher is carrying out is the data analysis technique of this research is to use regression while the research is using multiple regression, and one of the variables in this study is different from the researcher's variable. The same thing was also researched by Yudi. (2015) examined the effect of Compensation, Competency and Organizational Commitment on job satisfaction and performance of Cooperative employees (Case Study in Tuban District). Based on the results of compensation research, organizational competence and commitment together has a significant positive effect on job satisfaction. And in terms of compensation, competency and organizational commitment also have a positive effect on job satisfaction, besides competency, compensation, organizational commitment, and job satisfaction simultaneously have a positive effect on performance, in addition compensation, competency, and organizational have a positive positive effect on performance but Persial job satisfaction does not affect the performance of KSP employees in Tuban Regency. The difference between this research and the research that the researcher is conducting is that one of the variables in this study is different from the researcher variable.

\section{Conclusion}

This study aims to determine the effect of Compensation and Organizational Support on Job Satisfaction on the staff of the Pariaman District Secretariat. Based on the results of the study, the conclusions of this study can be described as follows: Organizational support has a significant positive effect on Job Satisfaction in the staff of the Regional Secretariat of Pariaman Regency. 3) It means that, the better organizational support, the better job satisfaction is generated.

\section{Bibliography}


Flippo, Erwin B. (2000). Manajemen Personalia, Terjemahan Moh. Masud. Cetakan. Kedelapan. Jakarta : Erlangga

Gronroos, C. 1990. Service Management and Marketing: Managing the Moment of Truth in Service Competition. Massachusetts: Lexington.

Mulia, Rizki Afri. 2019. "Analisis Faktor-Faktor Yang Mempengaruhi Kualitas Laporan Keuangan Pemerintah Daerah (Studi Pada Pemerintah Kabupaten Pasaman Barat).” 20199 (1): 15.

Mulia, R. A. (2019). Influence Of Public Policy, Participation Of Community And Education Level To Public Welfare In Padang Pariaman DistricT. Jurnal ELRIYASAH, 10(1), 37-56.

Mulia, R. A. (2019). Peranan Program Koperasi Jasa Keuangan Syariah Baitul Maal Wat Tamwil (Kjks Bmt) Dalam Pemberdayaan Pelaku Usaha Mikro Kecil Menengah Di Kota Padang. Ensiklopedia Sosial Review, 1(3).

Saputra, N., \& Mulia, R. A. (2020). Kontribusi Kompensasi Dan Motivasi Kerja Terhadap Kepuasan Kerja Pegawai Di Dinas Pendidikan Dan Kebudayaan Kabupaten Agam. Ensiklopedia Sosial Review, 2(1).

Meglino, B. M., Ravlin, E. C.,\& Adkins, C. L. (1989). A work values approach to corporate culture: a field test of the value congruence process and its 100 relationship to individual outcomes. Journal of Applied Psychology,74(3),424432.

Melayu SP. Hasibuan. 2002. Manajemen Sumber Daya Manusia. Edisi Revisi. Jakarta : Bumi Aksara.

Melayu SP. Hasibuan. 2001. Organisasi dan Motivasi. Jakarta : Bumi Aksara.

Melayu SP. Hasibuan. 2003. Organisasi dan Motivasi Dasar meningkatkan produktivitas. Bandung : Bina Aksara.

Melayu SP Hasibuan. 2007. Manajemen, Dasar, Pengertian, dan Masalah. Jakarta: Bumi Aksara.

Putri, R. P. (2018). Pemeriksaan Penggabungan Gugatan Ganti Kerugian Dalam Perkara Pidana Di Pengadilan Negeri Kelas 1B Bukittinggi. Soumatera Law Review, 1(1), 176-197. 